\title{
Apoptosis-Inducing Factor Triggered by Poly(ADP-Ribose) Polymerase and Bid Mediates Neuronal Cell Death after Oxygen-Glucose Deprivation and Focal Cerebral Ischemia
}

\author{
Carsten Culmsee, ${ }^{1}$ Changlian Zhu, ${ }^{3}$ Stefan Landshamer, ${ }^{1}$ Barbara Becattini, ${ }^{5}$ Ernst Wagner, ${ }^{1}$ Maurizio Pellechia, ${ }^{5}$ \\ Klas Blomgren, ${ }^{3,4}$ and Nikolaus Plesnila ${ }^{2}$ \\ ${ }^{1}$ Biotechnology and Pharmaceutical Biology, Department of Pharmacy and ${ }^{2}$ Laboratory of Experimental Neurosurgery, Walter Brendel Center for \\ Experimental Medicine, University of Munich, D-81377 Munich, Germany, ${ }^{3}$ Arvid Carlsson Institute of Neuroscience, Sahlgrenska Academy and \\ ${ }^{4}$ Department of Pediatrics, The Queen Silvia Children's Hospital, Göteborg University, SE 40530 Göteborg, Sweden, and ${ }^{5}$ The Burnham Institute, La Jolla, \\ California 92037
}

Delayed neuronal cell death occurring hours after reperfusion is a hallmark of ischemic stroke and a primary target for neuroprotective strategies. In the present study, we investigated whether apoptosis-inducing factor (AIF), a caspase-independent proapoptotic protein, is responsible for neuronal cell death after glutamate toxicity and oxygen-glucose deprivation (OGD) in vitro and after experimental stroke in vivo. AIF translocated to the nucleus in which it colocalized with DNA fragmentation and nuclear apoptotic morphology after exposure to glutamate or OGD in cultured neurons or after transient middle cerebral artery occlusion (MCAo) in mice. Small inhibitory RNAmediated downregulation of AIF reduced glutamate- and OGD-induced neuronal apoptosis by 37 and $60 \%$, respectively $(p<0.01)$. Moreover, Harlequin mutant mice, which express AIF at low levels ( $\sim 20 \%$ of wild-type mice), displayed smaller infarct volumes $(-43 \%$; $p<0.03$ ) and showed dramatically reduced cell death in the ischemic penumbra after $45 \mathrm{~min}$ of MCAo compared with wild-type littermates. Inhibition of poly(ADP-ribose) polymerase and Bid reduced nuclear AIF translocation. These results provide the first evidence for a causal role of AIF in ischemic neuronal cell death. Therefore, caspase-independent cell death signaling may provide a promising novel target for therapeutic interventions in cerebrovascular diseases.

Key words: cerebral ischemia; stroke; neuronal cell death; apoptosis-inducing factor; poly(ADP-ribose) polymerase; Bid

\section{Introduction}

The only causal therapy for ischemic stroke is reperfusion. However, even if cerebral blood flow is reestablished quickly enough to prevent immediate cell death, a large population of initially surviving neuronal cells will die within the first few hours after reperfusion. Apoptotic signaling pathways are, among others, an established feature of this phenomenon termed "delayed ischemic cell death" (Mattson et al., 2000; Graham and Chen, 2001). Membrane-bound cell death receptors, e.g., DR3 and Fas-R, are activated after cerebral ischemia (Martin-Villalba et al., 1999; Harrison et al., 2000) and may initiate neuronal cell death by cleaving the upstream initiator caspase-8 (Velier et al., 1999) and subsequent activation of the extrinsic caspase pathway. In addition, caspase- 8 can activate the Bcl-2 family member protein Bid

Received March 1, 2005; revised Sept. 23, 2005; accepted Sept. 27, 2005.

This work was supported by a grant from Friedrich Baur Foundation (N.P.), the Swedish Research Council (K.B.), and the Swedish Child Cancer Foundation (K.B.). We thank U. Mamrak, Miriam Hoehn, and Melinda Kiss for technical support with animal surgery and cell culture experiments. We also express our gratitude to Mike Moskowitz for his help during the initial phase of this project. HT22 cells were a kind gift from Gerald Thiel (University of Saarland, Saarbrücken, Germany).

Correspondence should be addressed to Dr. Nikolaus Plesnila, University of Munich Medical Center, Grosshadern, Marchioninistrasse 15, 81377 Munich, Germany. E-mail: plesnila@med.uni-muenchen.de.

D01:10.1523/JNEUROSCI.2818-05.2005

Copyright $\odot 2005$ Society for Neuroscience 0270-6474/05/2510262-11\$15.00/0 after cerebral ischemia (Plesnila et al., 2001) thereby inducing cytosolic release of cytochrome $c$ from mitochondria after ischemia (Fujimura et al., 2000). Released cytochrome $c$ ultimately leads to cleavage and activation of caspase- 9 and caspase- 3 , representing the final steps of the intrinsic caspase pathway, shown previously to be involved in ischemic cell death (Namura et al., 1998; Krajewski et al., 1999; Le et al., 2002). Despite the important role of caspases for delayed neuronal death after experimental stroke and cerebral hypoxia-ischemia (Lo et al., 2003), recent findings suggest the involvement of additional, caspaseindependent mechanisms downstream of mitochondria, e.g., apoptosis-inducing factor (AIF) (Zhu et al., 2003; Plesnila et al., 2004).

AIF is a $67 \mathrm{kDa}$ flavoprotein with significant homology to bacterial and plant oxidoreductases, located in the mitochondrial intermembranous space (Susin et al., 1999). During release from mitochondria, AIF migrates to the nucleus in which it induces large-scale $(\sim 50 \mathrm{kbp})$ DNA fragmentation and apoptosis by a yet unknown, caspase-independent mechanism, as demonstrated in a variety of different cell types (Daugas et al., 2000), including neurons (Cregan et al., 2002; Fonfria et al., 2002; Yu et al., 2002; Penninger and Kroemer, 2003; Zhu et al., 2003; Plesnila et al., 2004; Wang et al., 2004). In vivo, AIF is indispensable for mouse morphogenesis (Joza et al., 2001) and translocates to the nucleus 
in animal models of Parkinson's disease (Arnoult et al., 2002; Wang et al., 2003), epilepsy (Cheung et al., 2005), perinatal hypoxia-ischemia (Zhu et al., 2003; Zhu et al., 2004), brain trauma (Zhang et al., 2002), and ischemic stroke (Cao et al., 2003; Komjati et al., 2004; Plesnila et al., 2004). However, because AIF knock-out mice die early during embryonic development (Joza et al., 2001) and are thus not available for models of cerebral ischemia, it remained unclear whether AIF has a causal role for delayed ischemic cell death or if it is just a bystander in the cell death process.

The aim of the current study was to follow up our previous findings on AIF translocation after cerebral ischemia (Zhu et al., 2003; Plesnila et al., 2004) and investigate the causal relationship between mitochondrial AIF release and ischemic cell death in vivo using Harlequin (HQ) mutant mice expressing low levels of AIF and in vitro using small inhibitory RNA (siRNA)-mediated downregulation of AIF. Our findings strongly suggest that AIF greatly contributes to ischemic cell death in neurons and may therefore be a potential novel target for the treatment of acute and chronic neurodegenerative diseases and other disorders in which ischemic cell death is a prominent feature.

\section{Materials and Methods}

Cell culture and induction of neuronal cell death. Primary rat embryonic hippocampal neurons (Culmsee et al., 2002) were cultured in Neurobasal medium with $2 \%$ (v/v) B27 supplement, 2 mM glutamine, and $100 \mathrm{U} / \mathrm{ml}$ penicillin/streptomycin (Invitrogen, San Diego, CA). Cultures contain $>95 \%$ neurons as routinely controlled by neuronal-specific nuclear protein (NeuN) immunostaining (Culmsee et al., 2002). In 9- to 10-d-old primary neurons, the culture medium was replaced with Locke's solution (in mM: $154 \mathrm{NaCl}, 5.6 \mathrm{KCl}, 2.3 \mathrm{CaCl}_{2}, 1.0 \mathrm{MgCl}_{2}, 3.6 \mathrm{NaHCO}_{3}, 5$ glucose, and 5 HEPES, pH 7.2) or Earl's balanced salt solution (EBSS) medium (in $\mathrm{mg} / \mathrm{l}: 6800 \mathrm{NaCl}, 400 \mathrm{KCl}, 264 \mathrm{CaCl}_{2} \times 2 \mathrm{H}_{2} \mathrm{O}, 200 \mathrm{MgCl}_{2} \times 7 \mathrm{H}_{2} \mathrm{O}, 2200$ $\mathrm{NaHCO}_{3}, 140 \mathrm{NaH}_{2} \mathrm{PO}_{4} \times \mathrm{H}_{2} \mathrm{O}$, and 1000 glucose, $\mathrm{pH}$ 7.2) immediately before glutamate treatment $(20 \mu \mathrm{M}, 24-48 \mathrm{~h})$. At 9-10 d in vitro (DIV), these neurons express NMDA receptors and are therefore susceptible to glutamate-induced excitotoxicity (Culmsee et al., 2002). For oxygenglucose deprivation (OGD), glucose-free EBSS medium supplemented with gentamycin $(5 \mathrm{mg} / \mathrm{l})$ was purged with $\mathrm{N}_{2} / \mathrm{CO}_{2}(95 \% / 5 \%)$ for 30 min, resulting in an oxygen content of $2-3 \%$. Neurons were then washed three times with this medium and incubated for $4 \mathrm{~h}$ in an oxygen-free $\mathrm{N}_{2} / \mathrm{CO}_{2}(95 \% / 5 \%)$ atmosphere. Control cultures were incubated in EBSS with $10 \mathrm{~mm}$ glucose. Thereafter, the medium was replaced by standard culture medium (see above). Four, 8 , and $24 \mathrm{~h}$ after onset of OGD, cells were fixed with $4 \%$ formaldehyde in PBS for immunocytochemistry and quantification of cell death.

HT22 cells were cultured in DMEM (Invitrogen) supplemented with $10 \%$ heat-inactivated fetal calf serum, $100 \mathrm{U} / \mathrm{ml}$ penicillin, $100 \mu \mathrm{g} / \mathrm{ml}$ streptomycin, and $2 \mathrm{~mm}$ glutamine (Rossler et al., 2004). Glutamate (1-2 $\mathrm{mm}$ ) or staurosporine (300 nM) were added to the serum-containing medium, and cell viability was evaluated $18-20 \mathrm{~h}$ later.

Evaluation of apoptosis and cell viability. Cultured neurons or brain sections were stained with the fluorescent DNA-binding dye 4',6diamidino-2-phenylindole dihydrochloride (DAPI) or Hoechst 33342, respectively (Plesnila et al., 2004). Stained nuclei were visualized under epifluorescence illumination $(340 \mathrm{~nm}$ excitation and $510 \mathrm{~nm}$ barrier filter) using a $20 \times$ objective. Neurons with condensed and fragmented nuclei were considered apoptotic. In some experiments, neuronal cell damage was also determined by a combination of propidium iodide (PI) and calcein staining, which indicates the ability of healthy neurons to metabolize the nonfluorescent calcein-AM to fluorescent calcein and to prevent cellular PI uptake. Two hundred cells per culture were counted, and counts were made in at least four separate cultures per treatment condition without knowledge of the treatment history. Cell viability in HT22 cells was determined in 96-well plates by 3-(4,5-dimethylthiazol2-yl)-2,5-diphenyltetrazolium bromide (MTT) reduction at $0.25 \mathrm{mg} / \mathrm{ml}$ for $2 \mathrm{~h}$ (Liu et al., 1997). The reaction was terminated by adding a solu- bilization solution containing 10\% SDS and $0.6 \%$ acetic acid in dimethylsulfoxide, and absorbance was then determined at $590 \mathrm{~nm}$ (SpectraFluorplus; Tecan, Durham, NC).

AIF gene silencing. AIF-siRNA was generated using the recombinant Dicer enzyme kit following the instructions of the manufacturer (Gene Therapy Systems, San Diego, CA). Briefly, an AIF cDNA template (750 bp) for T7-RNA polymerase in vitro transcription was generated from mouse or rat mRNA by reverse transcription (RT)-PCR using the following primers: forward, 5' -GCG TAA TAC GAC TCA CTA TAG GGA GAT CCA GGC AAC TTG TTC CAGC-3'; and reverse, 5' -GCG TAA TAC GAC TCA CTA TAG GGA GAC CTC TGC TCC AGC CCT ATC G-3' (initial denaturation at $95^{\circ} \mathrm{C}$ for $2 \mathrm{~min} ; 28-30$ cycles of $30 \mathrm{~s} 95^{\circ} \mathrm{C}, 1 \mathrm{~min}$ $57^{\circ} \mathrm{C}$, and $2 \mathrm{~min} 72^{\circ} \mathrm{C}$; and final extension at $70^{\circ} \mathrm{C}$ for $10 \mathrm{~min}$ ). The cDNA template was precipitated and purified, and in vitro transcription was performed by using the TurboScript-T7-Transcription kit (Gene Therapy Systems). The resulting double-stranded RNA template was then exposed to the recombinant Dicer enzyme at $37^{\circ} \mathrm{C}$ for $16 \mathrm{~h}$ overnight, and the siRNA fragments were again purified on the RNA Purification Columns 1 and 2 of the manufacturer (Gene Therapy Systems). Lipofectamine (Invitrogen) and AIF-siRNA or nonfunctional mutant RNA (5'-AAG AGA AAA AGC GAA GAG CCA-3'; Dharmacon, Lafayette, $\mathrm{CO})$ were dissolved separately in Optimem I (Invitrogen). After $10 \mathrm{~min}$ of equilibration at room temperature, each RNA solution was combined with the respective volume of the Lipofectamine solution, mixed gently, and allowed to form siRNA liposomes for an additional $20 \mathrm{~min}$ at room temperature. The transfection mixture was added to the antibiotic-free cell culture medium to a final concentration of 20 nM RNA and 1.5 or 2 $\mu \mathrm{l} / \mathrm{ml}$ Lipofectamine in primary neurons or HT22 cells, respectively. Controls were treated with $100 \mu \mathrm{l} / \mathrm{ml}$ Optimem only and vehicle controls with $1.5-2 \mu \mathrm{l} / \mathrm{ml}$ Lipofectamine.

$R T$-PCR. Total RNA was extracted (Nucleospin RNA II kit; MachereyNagel, Düren, Germany), and RT-PCR was performed as described previously (Culmsee et al., 2002). Primers and PCR conditions for AIF were the same as given previously. Primers for glyceraldehyde-3-phosphate dehydrogenase (GAPDH) were as follows: forward, 5'-CGT CTT CAC CAC CAT GGA GAA GGC-3'; and reverse, 5'-AAG GCC ATG CCA GTG AGC TTC CC-3'. PCR for GAPDH was performed as follows: initial denaturation at $95^{\circ} \mathrm{C}$ for $2 \mathrm{~min}$; amplification by 26 cycles of $30 \mathrm{~s}$ $95^{\circ} \mathrm{C}, 1 \mathrm{~min} 57^{\circ} \mathrm{C}$, and $2 \mathrm{~min} 70^{\circ} \mathrm{C}$; and a final extension at $70^{\circ} \mathrm{C}$ for 10 min. RT-PCR products were visualized under UV illumination after electrophoresis on a $1.5 \%$ agarose gel containing ethidium bromide.

Characterization of vascular anatomy. HQ mice and their respective littermates $(n=5$ each) were killed in deep halothane anesthesia by transcardial perfusion with $4 \%$ paraformaldehyde (PFA). Thereafter, $200 \mu \mathrm{l}$ of India ink was infused transcardially. The brains were removed, and the territories of both middle cerebral arteries on the dorsal surface of the brain together with the development of the posterior communicating artery were quantified on a scale between 0 (no anastomosis) and 3 (fully developed anastomosis), as described previously (Murakami et al., 1998).

Transient focal cerebral ischemia. Male C57BL/6 mice (body weight, 18-22 g; Charles River Laboratories, Wilmington, MA) or HQ mice and their wild-type littermates (The Jackson Laboratory, Bar Harbor, ME) were subjected to transient middle cerebral artery occlusion (MCAo) as described previously (Plesnila et al., 2001, 2004). Briefly, a siliconecoated 8-0 nylon monofilament was pushed into the internal carotid artery until blood flow in the MCA territory decreased as determined by laser Doppler fluxmetry. Forty-five min after MCAo, ischemia was terminated by removal of the intraluminal suture. C57BL/6 mice were perfusion fixed with $4 \%$ PFA in deep halothane anesthesia $1,2,4,8$, and $24 \mathrm{~h}$ after MCAo, and brains were removed, postfixed in PFA for $24 \mathrm{~h}$, dehydrated, and embedded in paraffin. Coronal sections $(5 \mu \mathrm{m})$ from the infarct area were subjected to immunohistochemical analysis for nuclear AIF translocation, activation of caspase-3, and DNA damage. Brains of HQ mice and wild-type littermates were removed $24 \mathrm{~h}$ after MCAo, flash frozen, and cut $(10 \mu \mathrm{m})$. Eleven sections (500 $\mu \mathrm{m}$ apart), including the middle cerebral artery territory, were stained with cresyl violet or DAPI for quantification of infarct area or evaluation of ischemic cell death, 
Table 1. Physiological parameters of HQ mice and littermate controls during surgery

\begin{tabular}{|c|c|c|c|c|}
\hline & \multicolumn{2}{|l|}{ Before ischemia } & \multicolumn{2}{|l|}{ During ischemia } \\
\hline & Controls $(n=6)$ & $\mathrm{HQ}(n=8)$ & Controls $(n=6)$ & $\mathrm{HQ}(n=6)$ \\
\hline $\mathrm{MAP}(\mathrm{mmHg})$ & $94 \pm 7$ & $92 \pm 15$ & $83 \pm 10$ & $73 \pm 16$ \\
\hline $\mathrm{pH}$ & $7.33 \pm 0.07$ & $7.26 \pm 0.08$ & $7.25 \pm 0.05$ & $7.18 \pm 0.09$ \\
\hline $\mathrm{pCO}_{2}(\mathrm{mmHg})$ & $35 \pm 8$ & $38 \pm 8$ & $46 \pm 11$ & $51 \pm 8$ \\
\hline $\mathrm{pO}_{2}(\mathrm{mmHg})$ & $148 \pm 25$ & $155 \pm 15$ & $141 \pm 15$ & $129 \pm 24$ \\
\hline
\end{tabular}

Physiological parameters were not different between $\mathrm{HQ}$ mice $(n=6-8)$ and their wild-type littermates $(n=6)$ regarding mean arterial blood pressure $(\mathrm{MAP})$, arterial pH $(\mathrm{pH})$, arterial partial pressure for carbon dioxide $\left(\mathrm{pC} \mathrm{O}_{2}\right)$, and arterial partial pressure for oxygen $\left(\mathrm{pO}_{2}\right)$ before surgery and $30 \mathrm{~min}$ after occlusion of the middle cerebral artery.

respectively. Infarct volume was calculated by multiplying infarct areas with the distance between sections.

Because arterial catheterization is not compatible with long-term survival in mice, animal physiology was assessed in a separate group of animals ( $n=5$ each).

Inhibition of poly(ADP-ribose) polymerase activity. Poly(ADP-ribose) polymerase 1 (PARP1) activity was inhibited by using the potent and highly specific inhibitor PJ-34 as described previously (Abdelkarim et al., 2001). PJ-34 was applied 15 min before OGD in a final concentration of $1 \mu \mathrm{M}$. In vivo male C57BL/6 mice (body weight, 18-22 g; Charles River Laboratory) received $10 \mathrm{mg} / \mathrm{kg}$ of the drug $15 \mathrm{~min}$ before $45 \mathrm{~min}$ of MCAo. Brains were stained for AIF and active caspase-3 $4 \mathrm{~h}$ after reperfusion.

Inhibition of Bid. Conversion of Bid to tBid, which migrates to the mitochondrial membrane and forms pores in the mitochondrial membrane, was prevented by maintaining Bid in an inactive conformation using $2 \mu \mathrm{M}$ of the highly specific inhibitor Bl6c9 (Becattini et al., 2004).

Immunostaining. Immunocytochemistry or immunohistochemistry was performed in cultured cells or brain slices, as described previously (Plesnila et al., 2004). Briefly, nonspecific binding was blocked for $30 \mathrm{~min}$ with $4 \%$ horse serum in PBS. Anti-AIF ( $2 \mu \mathrm{g} / \mathrm{ml}$; sc-9416; Santa Cruz Biotechnology, Santa Cruz, CA) was applied in TBS containing 1\% BSA and $0.1 \%$ Triton $\mathrm{X}-100$, incubated for $60 \mathrm{~min}$ at room temperature, followed by a biotinylated horse anti-goat antibody $(6 \mu \mathrm{g} / \mathrm{ml}$ in PBS $)$ for $60 \mathrm{~min}$. Endogenous peroxidase activity was blocked with $3 \% \mathrm{H}_{2} \mathrm{O}_{2}$ in PBS for $5 \mathrm{~min}$. Visualization was performed using a Vectastain ABC Elite kit with $0.5 \mathrm{mg} / \mathrm{ml} 3,3^{\prime}$-diaminobenzidine enhanced with $15 \mathrm{mg} / \mathrm{ml} \mathrm{am}$ monium nickel sulfate, $2 \mathrm{mg} / \mathrm{ml} \beta$-D-glucose, $0.4 \mathrm{mg} / \mathrm{ml}$ ammonium chloride, and $0.01 \mathrm{mg} / \mathrm{ml} \beta$-glucose oxidase (Vector Laboratories, Burlingame, CA). Negative controls, in which the primary antibody was omitted, were completely blank, and preabsorption with the peptide provided by the manufacturer abolished the staining. A similar protocol was used for active caspase- 3 staining (anti-active caspase- 3 antibody; 67342A; BD Biosciences PharMingen, San Diego, CA). Detection of DNA damage was achieved with a biotinylated oligonucleotide hairpin probe (HPP) with one base overhang in the $3^{\prime}$ end as described previously (Didenko et al., 1998; Zhu et al., 2000, 2003; Plesnila et al., 2004). Multiple immunolabeling of cells followed by nuclear staining with DAPI or Hoechst 33342 was done as reported previously (Plesnila et al., 2004). Quantification of cells positively stained for AIF, active caspase-3, or DNA damage was achieved by cell counting in areas of cortex and striatum affected by ischemia (mitogen-activated protein- 2 negative). Three randomly chosen visual fields (one visual field, $0.196 \mathrm{~mm}^{2}$ ) were counted in each region by an investigator without knowledge of the experimental conditions.

Western blot analysis. Western Blot analysis was performed as described previously (Plesnila et al., 2001, 2004). Briefly, the blot was probed with an affinity-purified goat polyclonal antibody raised against a peptide mapping the C terminus of mouse AIF (1:500; sc-9416; Santa Cruz Biotechnology) at $4^{\circ} \mathrm{C}$ overnight. Membranes were then exposed to a rabbit anti-goat HRP-conjugated secondary antibody (1:5000; Vector Laboratories), followed by a chemiluminescence detection of antibody binding (ECL; Amersham Biosciences, Arlington Heights, IL). Equal protein loading was demonstrated by stripping and reprobing the membrane with a monoclonal anti- $\beta$-actin antibody (AC- $15 ; 1: 10,000$; Santa Cruz Biotechnology) and a secondary anti-mouse HRP-conjugated antibody (Vector Laboratories).

Statistical analysis. All data are given as means \pm SD if not indicated otherwise. For statistical comparisons between groups in cell culture experiments, ANOVA followed by Scheffè's post hoc test was used. For in vivo experiments, the Kruskal-Wallis ANOVA on ranks test was used followed by Dunnett's all pairwise multiple comparison procedure as post hoc test. Calculations were performed with a standard statistical software package (SigmaStat 2.0; Jandel Scientific, Corte Madera, CA).

\section{Results}

\section{Animal physiology}

Blood pressure and blood gases were within the physiological range before and during surgery and were not different between groups (Table 1). Cerebral blood flow in the MCA territory was reduced to the same level in HQ mice and wild-type littermates ( $12 \pm 4$ and $10 \pm 5 \%$ of baseline, respectively). The cerebrovascular anatomy, particularly the anastomosis between the anterior (carotid arteries) and posterior (basilar artery) cerebral circulation, which may affect outcome after MCAo in mice, was quantified and found not to be different between HQ mice and their wild-type littermates $(2.3 \pm 0.7$ vs $2.3 \pm 0.5$ arbitrary units $)$.

\section{Downregulation of AIF using siRNA technology in cell culture}

Addition of siRNA targeting AIF to immortalized hippocampal neurons (HT22 cells) or primary cultured neurons induced downregulation of AIF mRNA by $85 \%$ within $48 \mathrm{~h}$ in a dosedependent manner as identified by RT-PCR and densitometry (Figs. $1 B, 2 A$ ). To increase the probability of a successful downregulation of AIF, we generated multiple siRNA constructs using recombinant DICER enzyme. Cell viability, mRNA levels of the reference gene GAPDH, and protein levels of $\beta$-actin were not affected by AIF-siRNA (Figs. $1 B, 2 A$ ), indicating that the siRNA construct was specific, nontoxic, and did not affect total cellular mRNA or protein. Silencing of AIF mRNA caused $80 \%$ reduction of AIF protein within $48 \mathrm{~h}$, as demonstrated in HT22 cells and primary cultured neurons by Western blot analysis (Figs. $1 \mathrm{~B}, 2 \mathrm{~A}$ ) and immunocytochemistry (Fig. 1C, Control, bottom panels).

\section{Downregulation of AIF reduced glutamate- and oxygen-glucose deprivation-induced cell death in vitro} Addition of $2 \mathrm{~mm}$ glutamate to immortalized hippocampal neurons induced translocation of AIF to the nucleus, as demonstrated by immunocytochemistry and Western blot analysis (Fig. $1 A)$. Downregulation of AIF protein by siRNA significantly enhanced neuronal survival after exposure to lethal levels of glutamate, a paradigm associated with nuclear AIF translocation ( $72 \pm 7$ vs $35 \pm 3 \%$ in controls and $42 \pm 3$ vs $16 \pm 1 \%$ in controls after 1 and 2 mM glutamate, respectively; $p<0.001$ ) (Fig. $1 D)(\mathrm{Yu}$ et al., 2002). Of note, AIF-siRNA-treated cells surviving glutamate toxicity did not show nuclear AIF translocation, thereby stressing the specific role for AIF during the cell death process (Fig. 1C). Comparable results were also obtained with a single AIF-siRNA sequence, which also specifically reduced AIF mRNA and protein levels (data not shown). The role of AIF for neuronal 
A
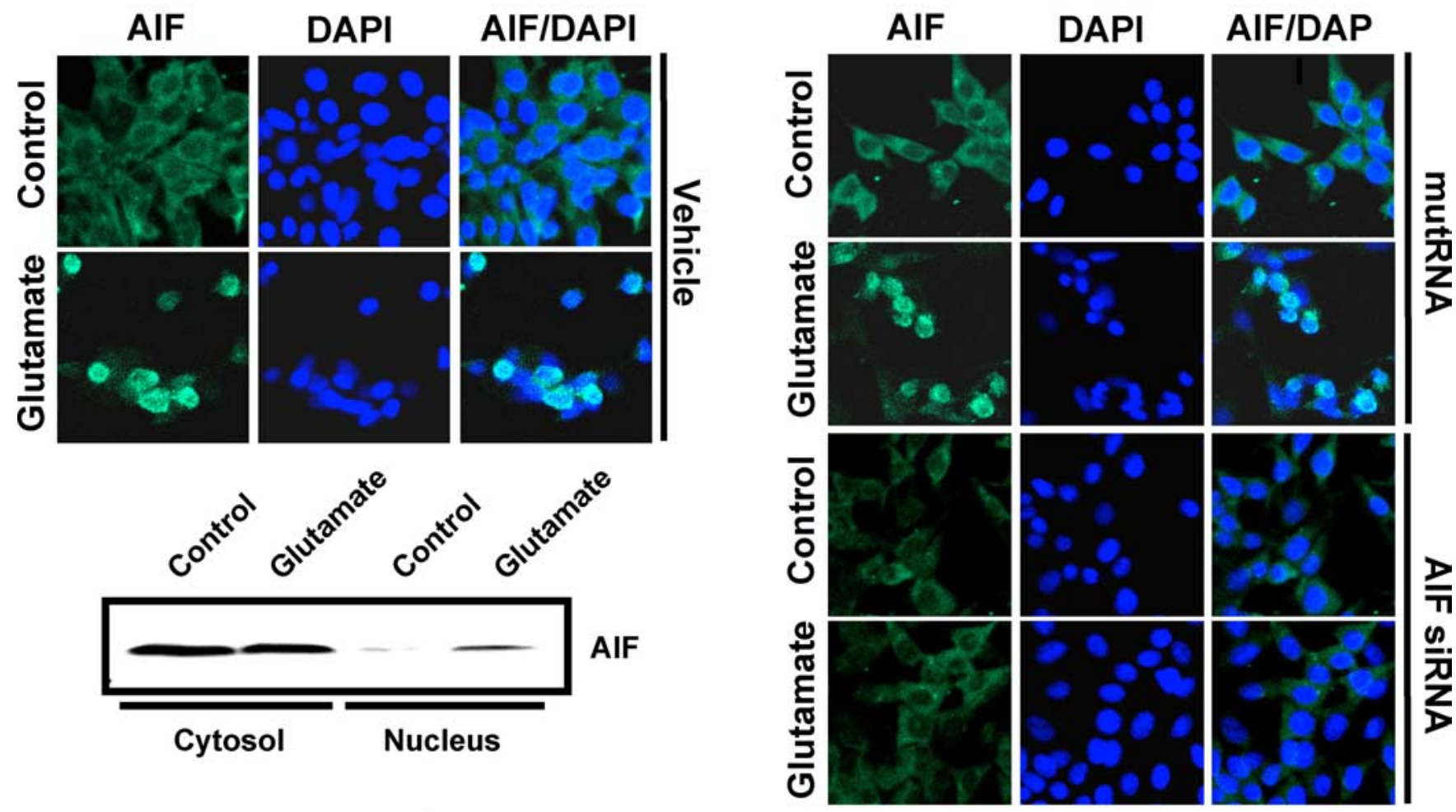

$\frac{D}{\pi}$
0
$\frac{0}{\pi}$
$\frac{7}{D}$
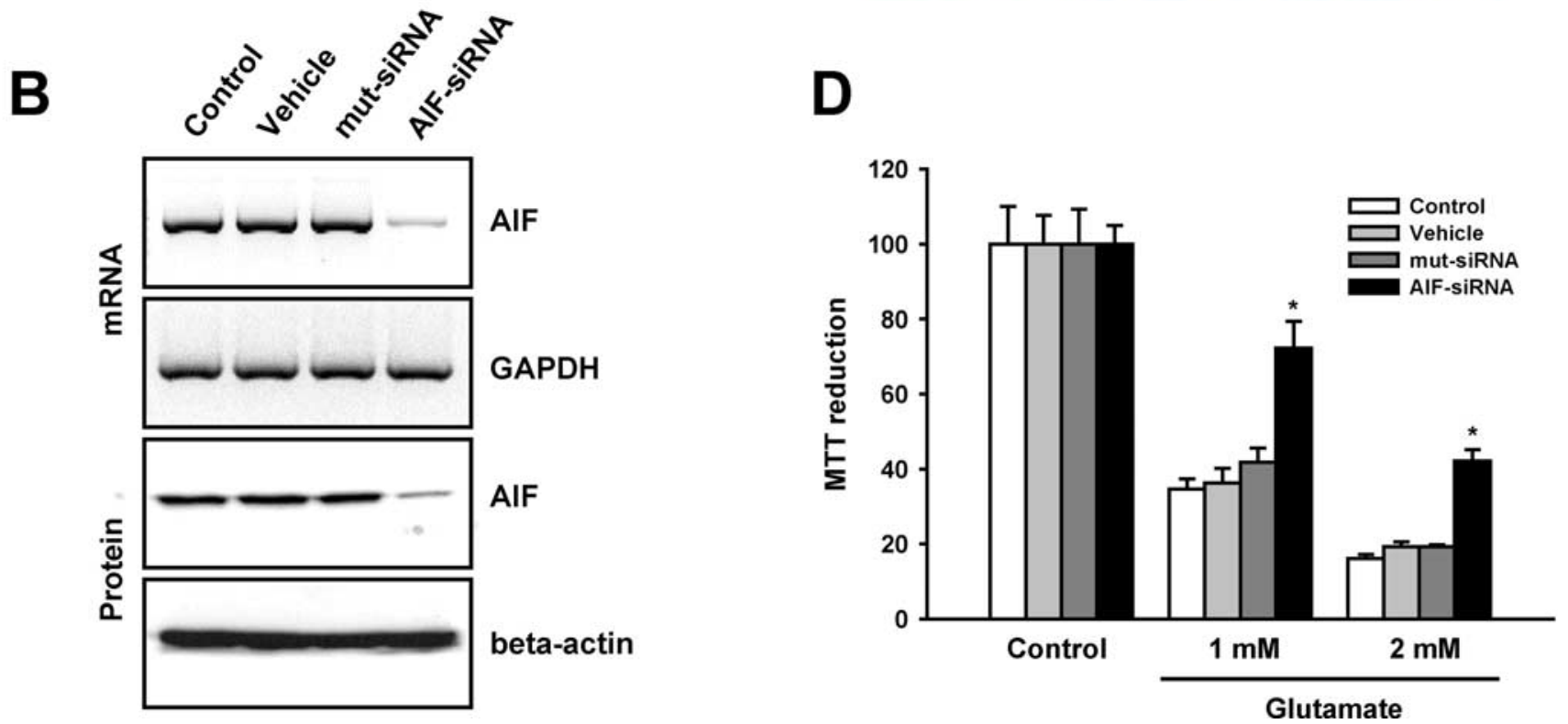

Figure 1. AlF-siRNA knock-down attenuates glutamate-induced neuronal cell death in hippocampal neurons. $\boldsymbol{A}$, Top row, Confocal laser scanning microscope images of AIF immunoreactivity (green) under control conditions and after $18 \mathrm{~h}$ exposure to glutamate $(2 \mathrm{~mm})$ in immortalized hippocampal neurons (HT22 cells). Costaining with DAPI (dark blue) allowed the identification of nuclear translocation of AIF (AIF/DAPI, light blue). Bottom row, Western blot analysis of AIF protein in the crude cytosolic and in the nuclear fractions before and after exposure to $2 \mathrm{~mm}$ glutamate. $B$, RT-PCR analysis of AIF RNA (top 2 rows) and Western blot analysis of AIF protein levels (bottom 2 row) in HT22 cells pretreated with $20 \mathrm{~nm} \mathrm{AIF} \mathrm{siRNA} \mathrm{for} 48 \mathrm{~h}$. Controls were treated with mutant siRNA. RT-PCR with primers specific for GAPDH and anti- $\beta$-actin antibodies were used as controls for equal mRNA and protein amounts, respectively. HT22 cells were pretreated with vehicle (Lipofectamine), nonfunctional mutant siRNA (mut-siRNA), or AlF-siRNA for $48 \mathrm{~h}$. C, Confocal laser scanning microscope images of AlF immunoreactivity (green) and nuclear DAPI staining (dark blue). Downregulation of AIF by siRNA (see above) resulted in inhibition of nuclear AIF translocation after $18 \mathrm{~h}$ of exposure to glutamate ( $2 \mathrm{~mm}$ ). D, Cell viability was determined by the MTT assay, $20 \mathrm{~nm}$ mutant siRNA, or AIF-siRNA for $48 \mathrm{~h}$ before $18 \mathrm{~h} 1-2 \mathrm{~mm}$ glutamate exposure. Cell viability in glutamate-exposed cultures pretreated with AlF-siRNA was significantly enhanced compared with controls $\left(n=8\right.$; $\left.{ }^{*} p<0.001\right)$.

cell death is further supported by the fact that AIF-siRNA did not influence staurosporine-induced cell death, a paradigm that does not necessarily require AIF for induction of apoptosis (Susin et al., 2000; Cande et al., 2004) (data not shown).
The results obtained with immortalized HT22 neurons, which do not express NMDA receptors and die as a result of glutathione depletion after glutamate-induced inhibition of cystine import via the glutamate-cystine antiporter (Schubert and Piasecki, 
2001), were further extended by observations made in primary hippocampal neurons in which glutamate mediates excitotoxicity through activation of NMDA receptors. In these cells, addition of AIFsiRNA induced complete loss of AIF mRNA within $24-72 \mathrm{~h}$ and significant reduction of AIF protein $48 \mathrm{~h}$ after onset siRNA treatment (Fig. 2A). Housekeeping proteins such as GAPDH or $\beta$-actin were not affected by AIF-siRNA, and mutant siRNA control sequences affected neither AIF mRNA or protein levels nor the housekeeping proteins (Fig. 2 A). siRNAmediated knock-down of AIF resulted in a significant reduction of apoptotic nuclei after glutamate-induced neuronal cell death (Fig. 2B). After glutamate treatment, $>90 \%$ of cells displayed condensed nuclei in control cultures, whereas only $58 \pm 8 \%$ of AIF-siRNA-treated cells showed signs of nuclear apoptosis $(p<$ 0.01) (Fig. 2C).

To investigate whether the findings obtained after glutamate toxicity can be expanded to in vitro conditions modeling the situation in the ischemic brain more closely, we performed additional experiments on primary cultured neurons in an oxygen-glucose deprivation paradigm. Eight hours after $4 \mathrm{~h}$ of OGD, AIF was identified in the nucleus of severely damaged neurons showing nuclear shrinkage (Fig. 3A). Significant numbers of neurons displaying AIF nuclear staining were observed already $4 \mathrm{~h}$ after OGD, a time point when no significant morphological neuronal damage could be observed (Fig. 3B), demonstrating that AIF translocation from mitochondria to the nucleus precedes neuronal cell death. The hypothesis that AIF may have a causal role for hypoxia-hypoglycemia-induced neuronal cell death was proven by data obtained from AIF-siRNA-treated neuronal cultures subjected to OGD. Most control neurons displayed condensed, pyknotic nuclei $24 \mathrm{~h}$ after OGD, whereas many cells in the AIF-siRNA-treated cultures showed a normal nuclear morphology (Fig. 3C). Quantification revealed that AIF downregulation resulted in a reduction of OGD-induced cell death by $>50 \%$ $(p<0.01)($ Fig. 3D).

\section{Inhibition of PARP1 and Bid reduced nuclear AIF translocation and protected neurons from hypoxia- hypoglycemia-induced cell death}

In a first approach to explore the mechanisms of AIF nuclear translocation after OGD, we inhibited poly(ADP-ribose) polymerase 1 , a protein described previously to be responsible for AIF release from mitochondria during $N$-methyl- $N$-nitro- $N$ nitrosoguanidine-, $\mathrm{H}_{2} \mathrm{O}_{2}$-, and NMDA-induced cell death (Yu et al., 2002). One micromolar PJ-34, a highly specific PARP1 inhibitor (Abdelkarim et al., 2001), reduced nuclear AIF translocation (Fig. $4 A$ ) and protected neuronal cultured by more than $80 \%$
B

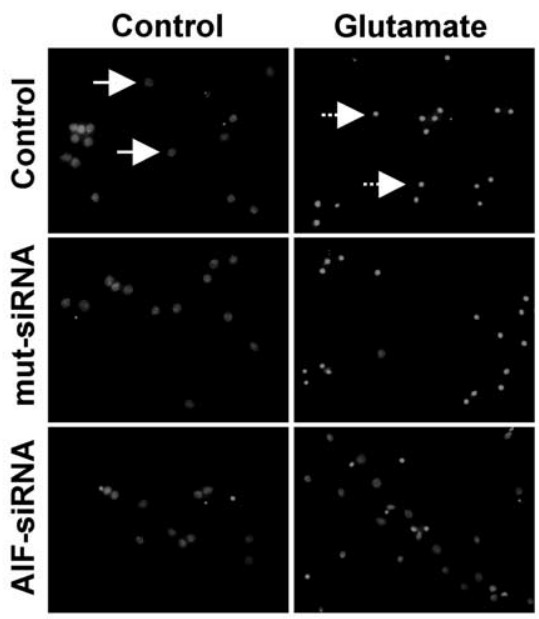

C

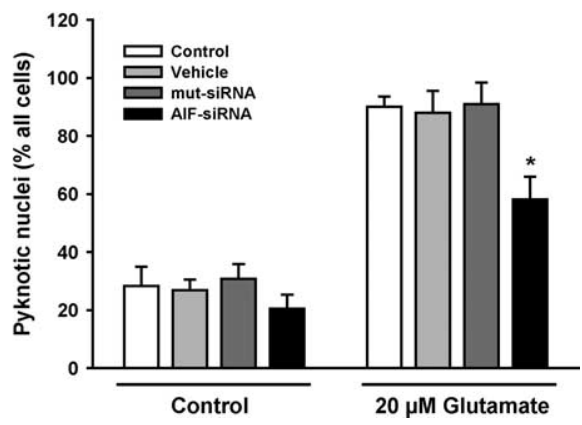

Figure 2. Reduced glutamate-induced apoptosis in primary neurons pretreated with AIF-siRNA. $A$, AIF mRNA and protein were significantly downregulated, as demonstrated by RT-PCR (top row) and Western blot analysis (bottom row), respectively, in the other cultures exposed to glutamate ( $n=4 ;{ }^{*} p<0.01$ vs all other glutamate-treated groups).

from OGD-induced cell death (Fig. $4 B$ ), strongly suggesting that release of AIF from mitochondria after OGD is related to the activation of PARP1, subsequent poly-ADP-ribolysation, and depletion of mitochondrial nicotinamide adenine dinucleotide $\left(\mathrm{NAD}^{+}\right.$) (Yu et al., 2002).

Because translocation of AIF to the nucleus after hypoxiaischemia is also modulated by proteins of the Bcl-2 family (Zhao et al., 2004) and Bid, a BH3-only member of the Bcl-2 protein family, contributes to post-ischemic neuronal cell death (Plesnila et al., 2001; Yin et al., 2002), we hypothesized that Bid may also be involved in the translocation of AIF to the nucleus after hypoxiahypoglycemia-induced neuronal cell death. Inhibition of Bid activation by $2 \mu \mathrm{M} \mathrm{Bl6c} 9$, which did not show any signs of toxicity even when given at a five times higher concentration $(10 \mu \mathrm{M})$, reduced nuclear AIF translocation and neuronal cell death after OGD to control levels $(p<0.01$ ) (Fig. $4 C, D)$. This result suggests that nuclear AIF translocation occurs downstream of Bid activa- 
A

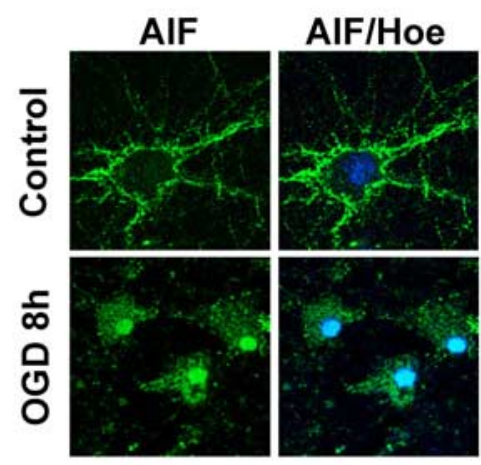

B
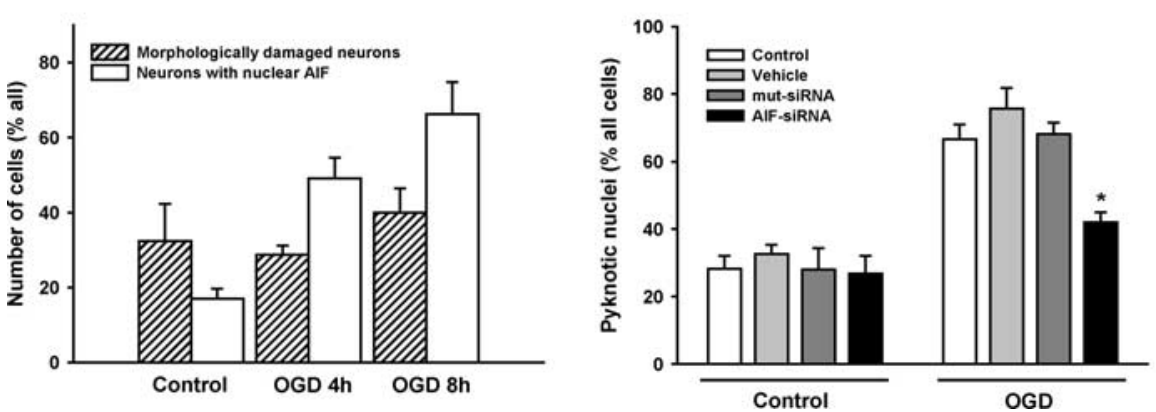

Figure 3. Reduced ischemic cell death after oxygen/glucose deprivation in primary neurons pretreated with AIF-siRNA. $\boldsymbol{A}$, In control neurons (top row), AIF (green) is located outside the DAPI-stained nucleus (dark blue). Oxygen- glucose deprivation ( $8 \mathrm{~h}$ ) caused translocation of AIF (green) to the nucleus (dark blue) $4 \mathrm{~h}$ after reoxygenation. $\boldsymbol{B}$, Number of damaged neurons and neurons displaying nuclear AIF 4 and $8 \mathrm{~h}$ after reoxygenation after $4 \mathrm{~h}$ of oxygen-glucose deprivation. AlF translocates to the nucleus before signs of morphological neuronal damage [as determined by nuclear morphology after DAPI/Hoechst (Hoe) staining or propidium iodide/calcein staining] become evident. C, Primary hippocampal neurons were left untreated (Controls) or were pretreated with vehicle (Lipofectamine), 20 nm nonfunctional mutant siRNA (mut-siRNA), or 20 nm AIF-siRNA for 48 h. On DIV9, cells were exposed to $4 \mathrm{~h}$ of oxygen- glucose deprivation. Thereafter, neurons were fixed with paraformaldehyde, and apoptotic nuclei were quantified after staining with DAPI. Neurons pretreated with AIF-siRNA showed less pyknosis after OGD compared with nontreated neurons. D, Quantification of experiments described in $\boldsymbol{C}$. Pretreatment with AIF-siRNA significantly reduced apoptotic cell death compared with control cultures ( $n=4 ;{ }^{*} p<0.01$ vs all other glutamate-treated groups).

tion and that Bid may be responsible for the release of AIF from mitochondria.

\section{Expression of AIF in normal and ischemic brain}

In normal brains, AIF showed clearly extranuclear, i.e., cytoplasmic, staining (Fig. 5A, Control, left) that colocalized with cytochrome oxidase, a mitochondrial marker, as shown previously (Zhu et al., 2003; Plesnila et al., 2004). Significant AIF immunoreactivity was predominantly identified in neurons, as shown by colocalization with NeuN, a neuronal marker (Fig. 5A, Control, right). After MCA occlusion, a well established experimental model of stroke, AIF translocates to the nucleus of neurons already $2 \mathrm{~h}$ after the insult (Fig. 5A, $2 \mathrm{~h}$ ). Twenty-four hours after ischemia, nuclear AIF colocalizes with ischemic cell deathspecific DNA fragmentation, as shown by double staining with HPP, a specific marker of apoptosis-related DNA strand breaks (Zhu et al., 2000), and with nuclei displaying nuclear condensation (Fig. 5A, $24 \mathrm{~h}$ ). The time course of the number of cells with nuclear AIF staining in ischemic tissue correlates very well with the number of dead neurons after cerebral ischemia $\left(r^{2}>0.99\right)$ (Fig. $5 B$ ), suggesting a relationship between nuclear AIF translocation and cell death. This correlation was most pronounced in the ischemic penumbra, in which cell death occurs in a delayed manner (Lo et al., 2003). Only a fraction of neurons displaying DNA damage and nuclear AIF staining were also positive for active caspase-3 (Fig. 5C). These cells showed intense AIF staining and advanced nuclear pyknosis, suggesting that nuclear AIF translocation represents an early event during neuronal cell death signaling, whereas caspase- 3 activation occurs at a later stage or in a different population of cells.

\section{Neuroprotection in Harlequin mutant} mice after focal cerebral ischemia

HQ mice, which were shown recently to have an proviral insertion in intron 1 of the Aif gene (Klein et al., 2002), show an $80 \%$ reduction of AIF protein expression (Fig. $6 A$ ). Homozygous HQ mice were born at expected Mendelian ratios (data not shown), survived to adulthood, and did not show any apparent phenotype during young age compared with wild-type littermates, except patchy hair loss. Twentyfour hours after $45 \mathrm{~min}$ of focal cerebral ischemia, homozygous HQ mice displayed significantly smaller infarcts compared with wild-type littermates (Fig. 6B). Microscopic analysis of cortical tissue subjected to ischemia showed hardly any cell loss in HQ mice (Fig. 6C, top). Most neurons displayed normal nuclear morphology, as demonstrated by DAPI staining (Fig. 6C, HQ/HQ, bottom). In contrast, wild-type control animals showed pronounced cortical cell loss, cell shrinkage, and apoptosis-like nuclear condensation (Fig. 6C, Control). Histomorphometrical analysis demonstrated that HQ mice had smaller infarcts in all cortical regions of the brain affected by ischemia ( $p<0.05$ ) (Fig. $6 D$, top). Total infarct volume in HQ mice was reduced by $43 \%$ compared with wild type littermates (30.6 \pm 7.4 vs $53.5 \pm 5.2 \mathrm{~mm}^{3}$; $p<0.03$ ) (Fig. $6 D$, bottom). Separate analysis of infarct volumes in cortex and striatum, in which AIF expression was similar (Fig. 6E), revealed that almost all neuroprotection occurred in cortical tissue (Fig. $6 \mathrm{~A}$ ), i.e., the area of the brain in which infarcts develop in a delayed manner and ischemic cell death is most prominent after MCAo.

In contrast to most other mouse strains, e.g., C57BL/6 or 129/ $\mathrm{Sv}$, homozygous HQ mice and their wild-type littermates almost completely regained their pre-ischemic motor function $24 \mathrm{~h}$ after 45 min MCAo ( $0.25 \pm 0.27$ vs $0.5 \pm 0.45$ in controls; scale, $0-4)$. Accordingly, no statement about the effect of AIF downregulation on post-ischemic functional outcome can be made.

\section{Role of PARP1 for nuclear AIF translocation after focal cerebral ischemia}

To further explore the mechanisms by which AIF translocates to the nucleus and causes post-ischemic cell death, we pretreated C57BL/ 6 mice with $10 \mathrm{mg} / \mathrm{kg}$ of the specific PARP inhibitor PJ-34 30 min before MCAo. Inhibition of PARP resulted in a reduction 
of the number of AIF-positive nuclei in the cerebral cortex $4 \mathrm{~h}$ after reperfusion (Fig. $7 A$ ). Counting of cells displaying nuclear AIF in ischemic brain revealed that PARP inhibition prevented post-ischemic AIF translocation in 45 and $40 \%$ of all cortical and striatal neurons, respectively (Fig. 7B). Of note, PARP inhibition reduced AIF translocation also in the striatum, an area of the brain in which vehicle- and PJ-34treated mice show the same extent of final tissue damage. Accordingly, the observed reduction of nuclear AIF translocation cannot be explained as secondary to the reduction of tissue damage in PJ-34treated mice but was indeed mediated by reduced PARP1 activity.

To further investigate whether inhibition of AIF-mediated cell death is accompanied by a compensatory increase of caspase-3-mediated neuronal damage, we colabeled post-ischemic brain tissue for AIF and active caspase-3. Quantification of AIF- and active caspase-3-positive neuronal cells in the ischemic striatum, which is not protected by PARP inhibition (see above), clearly demonstrates that reduction of AIF-induced cell death did not increase the number of cells dying by caspase- 3 activation (Fig. $7 B$ ). These findings clearly show that AIF- and caspase-3mediated neuronal cell death signaling are independent of each other, and hence AIF represents a novel and independent cell death pathway in post-ischemic neurons.

\section{Discussion}

Our data strongly suggest that AIF is a mediator of neuronal cell death after ischemia-like conditions in vitro and after cerebral ischemia in vivo. We base our conclusion on the findings that (1) downregulation of AIF in primary cultured neurons reduced cell death after glutamate-induced glutathione depletion, glutamate-induced excitotoxicity, and oxygen-glucose deprivation (Figs. 1-3) and (2) Harlequin mutant mice, which express AIF at low levels, display significant neuroprotection after experimental stroke (Figs. 5, 6). Therefore, AIF plays a causal role for ischemic cell death and may represent a novel therapeutic target for treatment of acute cerebrovascular diseases.

It is well established that the final steps of delayed ischemic cell death are mediated by an intracellular signaling cascade initiated through the activation of caspase- 8 (Velier et al., 1999) by cell membrane-bound death receptors of the Fas/tumor necrosis factor family (Martin-Villalba et al., 1999; Harrison et al., 2000), resulting in caspase-3-mediated DNA fragmentation (Le et al., 2002). Caspase- 3 can be activated directly by caspase- 8 , but, in the case of cerebral ischemia, caspase- 3 activation seems to be mediated by cleavage of the proapoptotic Bcl-2 family member protein Bid (Plesnila et al., 2001). Bid initiates the release of cytochrome $c$ from mitochondria, thereby triggering the formation of the apoptosome complex that finally activates caspase-3 (Figs. $5,7)$. This concept has been validated by numerous studies show-
C

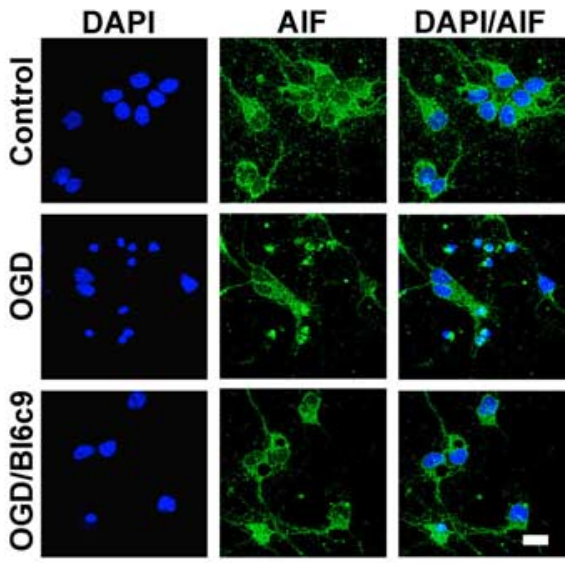

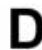

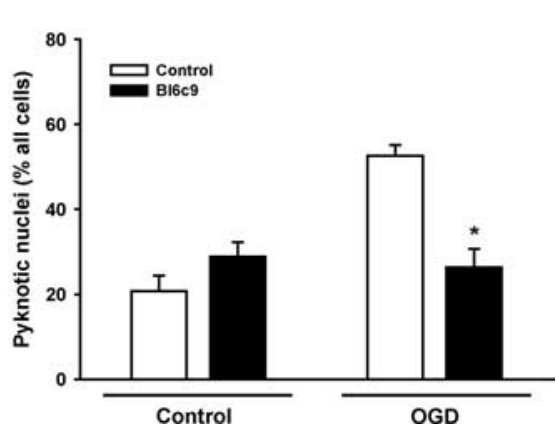

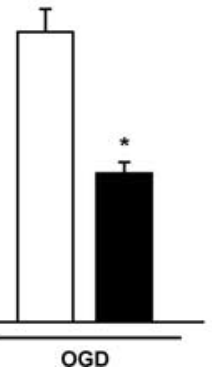

Figure 4. PARP1 and Bid inhibition reduced nuclear AIF translocation after oxygen-glucose deprivation in primary neurons. $\boldsymbol{A}$, caused translocation of AIF (green) to the nucleus (dark blue; middle row), a finding that was almost absent in cultures

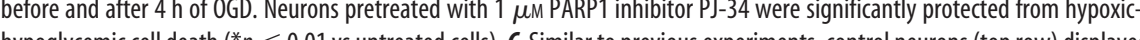
ypoglycemic cell death $\left({ }^{*} p<0.01\right.$ vs untreated cells). C, Similar to previous experiments, control neurons (top row) displayed

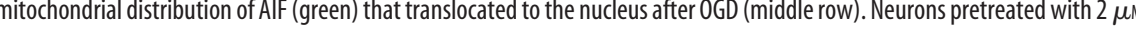
hypoxic- hypoglycemic cell death $\left({ }^{*} p<0.01\right.$ vs untreated neurons subjected to $\left.0 \mathrm{GD}\right)$. Control neurons were treated with $2 \mu \mathrm{m}$ (data not shown) and $10 \mu \mathrm{m} \mathrm{Bl6c9}$ to evaluate compound toxicity.

ing activation of all members of the cascade in post-ischemic neurons (for review, see Lo et al., 2003) and by experiments showing that mice deficient for death receptors (Martin-Villalba et al., 1999), Bid (Plesnila et al., 2001), or caspase-3 (Le et al., 2002) show neuroprotection after experimental stroke. Furthermore, upregulation of antiapoptotic molecules, which interact with this cascade, e.g., Bcl-2 or X-linked inhibitor of apoptosis protein, prevents post-ischemic neuronal cell death (Trapp et al., 2003).

Despite the central role assigned to caspase- 3 as a final step of cell death signaling in neurons in vitro (Lo et al., 2003), significant ischemic cell death-specific DNA damage after cerebral ischemia is also found in caspase-3 knock-out mice (Le et al., 2002) and in neurons of wild-type mice regardless of caspase- 3 activation in vivo (Didenko et al., 2002). Especially the findings in caspase-3 knock-out mice strongly suggest that alternative pathways of ischemic cell death-related DNA fragmentation independent of caspase 3 are activated after cerebral ischemia. This conclusion is also supported by the fact that, after cerebral ischemia, not only small, caspase 3-activated DNase-related DNA fragments of 200- 
A
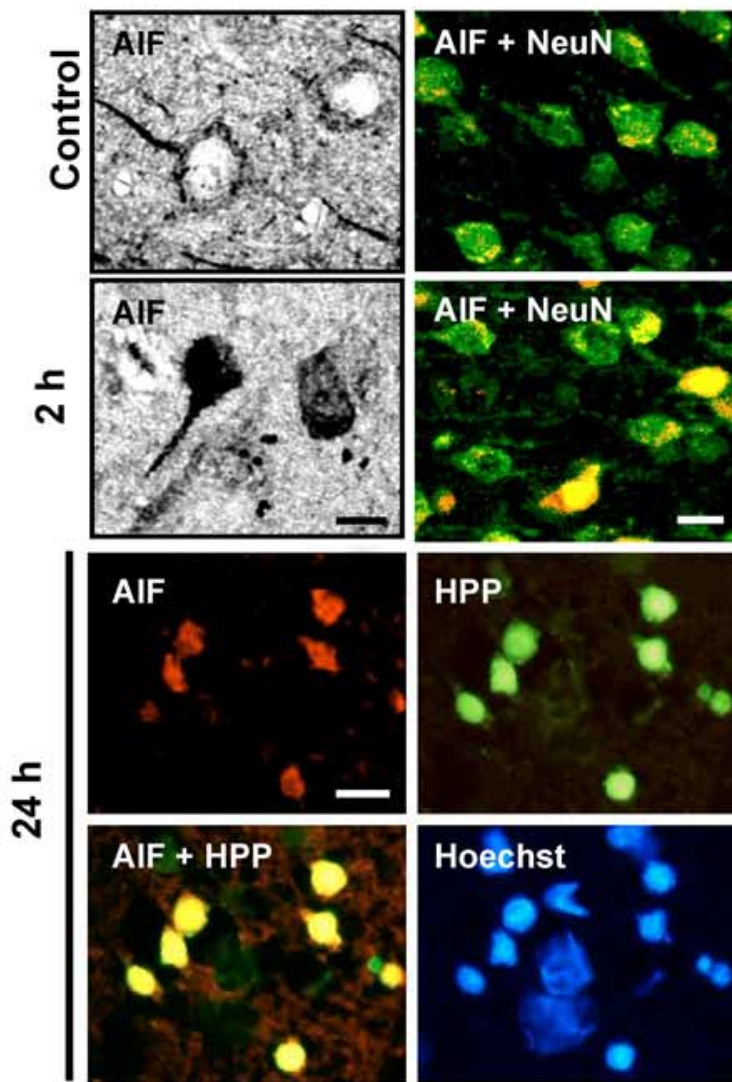

B

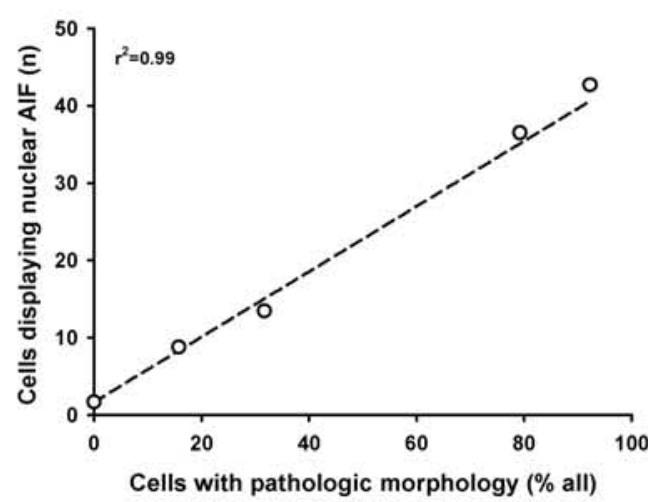

C
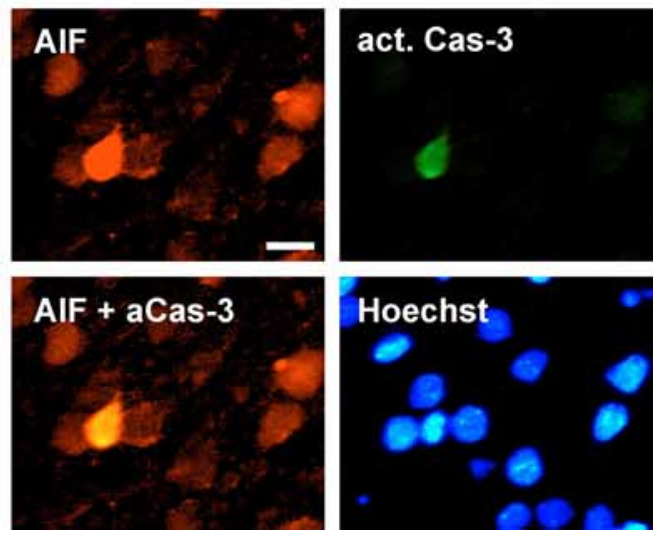

Figure 5. Alf translocates to the nucleus and is associated with DNA damage after focal cerebral ischemia. $A$, Photomicrographs of $\mathrm{C} 57 \mathrm{BL} / 6$ mouse brain sections showing cytoplasmic
1000 bp but also large, non-caspase-3-mediated DNA fragments of 50,000 bp are found in dying neurons (Charriaut-Marlangue et al., 1996). These findings are not compatible with a single role of caspase- 3 activation in post-ischemic cell death and may be explained by the involvement of AIF in this process, a molecule that induces large-scale DNA fragmentation independent of caspase-3 activation (Cande et al., 2004). This is further supported by previous reports from our laboratories (Zhu et al., 2003, 2004, 2005; Plesnila et al., 2004) and from others (Cao et al., 2003) showing that AIF translocates to the nucleus during postischemic cell death. However, these previous data do at best indicate that AIF may play a role in the pathophysiology of ischemic cell death by demonstrating only a temporal and spatial correlation between nuclear AIF translocation and neuronal cell death but no causality. Our current results strongly suggest for the first time that AIF has a causal role for post-ischemic neuronal cell death in vivo and in vitro. Downregulation of AIF by siRNA in vitro or by a spontaneous mutation in vivo reduced AIF translocation from mitochondria to the nucleus to undetectable levels (Fig. $1 B$ ), reduced excitotoxic and hypoxic-hypoglycemic neuronal damage in vitro (Figs. 1-3), and prevented cell death in the cortex of ischemic animals in vivo (Fig. 6). Our findings on the role of AIF for neuronal cell death are supported by three previous in vitro reports showing that AIF is responsible for DNA alkylation-induced cell death in cultured fibroblasts, for glutamate-induced neuronal cell death, and for apoptosis after UV irradiation in a B-lymphocyte cell line (Yu et al., 2002; Wang et al., 2004; Yuan et al., 2004). Additional support comes from a recent in vivo study showing reduced hippocampal neuronal cell death after kainate-induced seizures in AIF low-expressing HQ mice, the same mouse strain as used in the current study (Cheung et al., 2005)

The direct mechanisms responsible for AIF release from mitochondria after focal cerebral ischemia seem to be mediated, at least in part, by proteins of the Bcl-2 family. For example, herpes virus-mediated upregulation of antiapoptotic molecule Bcl-2 in brain parenchyma reduced AIF translocation in ischemic neurons after distal MCAo in rats (Zhao et al., 2004). Our data showing that inhibition of Bid prevents nuclear AIF translocation after hypoxia-hypoglycemia-induced neuronal cell death now strongly suggest that the proapoptotic $\mathrm{BH} 3$-only protein Bid is the actual Bcl-2 family member that is responsible for mitochondrial membrane pore formation and hence AIF release from mitochondria (Fig. 4C,D). This assumption is supported by the fact that deletion of the bid gene in mice shows a relatively moderate effect on mitochondrial cytochrome $c$ release after cerebral ischemia (Plesnila et al., 2001), suggesting that additional mecha-

\footnotetext{
$\leftarrow$

AlF immunostaining in normal neurons, as demonstrated by morphology and by colocalization with the neuronal marker NeuN (Control), and extensive nuclear translocation after transient MCAo (2h). At $24 \mathrm{~h}$ after ischemia, nuclear AIF immunoreactivity (red) was colocalized with the DNA damage marker HPP (green), both of which appeared only in cells displaying condensed, pyknotic nuclei, as judged by Hoechst chromatin staining (blue). Scale bar, $10 \mu \mathrm{m}$. B, Cells with intense AIF immunoreactivity in the nucleus were counted in the striatum and in cortex $1-24 \mathrm{~h}$ after transient MCAo and plotted against the number of cells with a morphology indicating cell death in adjacent, Nissl-stained sections. The close correlation between the two parameters $\left(r^{2}=0.99 ; p<0.001\right)$ indicates that nuclear translocation of AlF is closely associated to post-ischemic cell death in vivo ( $n=4$ per group). $C$, During the first hours of recovery after MCA0, there are multiple cells displaying nuclear AIF (red) but only scattered cells positive for active caspase-3 (green), indicating that AIF translocation either precedes activation of caspase-3 or displays an alternative signaling pathway of cell death in neurons.
} 
nisms have to be involved in Bid-mediated cell death downstream of mitochondria, such as AIF nuclear translocation.

So far, very little is known about in vivo mechanisms of AIF release upstream of mitochondria. In vitro studies in nonneuronal (Yu et al., 2002) and neuronal (Wang et al., 2004) cells demonstrate that AIF release from mitochondria is dependent on activation of PARP1, a molecule also responsible for neuronal cell death after cerebral ischemia (Endres et al., 1997; Chiarugi, 2005). Our current results support an important role for PARP1 for the release of AIF from mitochondria also after ischemic brain injury. Inhibition of PARP1 prevented AIF translocation from mitochondria to the nucleus after oxygenglucose deprivation in vitro (Fig. $4 A$ ) and focal cerebral ischemia in vivo (Fig. 7). Most importantly, nuclear AIF translocation was also prevented in brain areas not protected by PARP1 inhibition. This result clearly demonstrates that the release of AIF from mitochondria after cerebral ischemia depends on PARP1 activation but is independent of the PARP1 inhibitionmediated neuroprotection. Furthermore, the extent of caspase-3 activation was not affected by PARP inhibition. It has been suggested that mitochondrial $\mathrm{NAD}^{+}$depletion, which is caused by overactivation of PARP1, may represent the link between PARP1 activation and the release of AIF from mitochondria ( $\mathrm{Yu}$ et al., 2002). $\mathrm{NAD}^{+}$depletion, which was well documented after cerebral ischemia (Endres et al., 1997), occurs in parallel with mitochondrial membrane depolarization (Yu et al., 2002), together with nuclear condensation (Fig. 3A) but before the morphological signs of ischemic cell death in vitro and in vivo (Figs. $3 B, 5 A$ ), and is therefore the most likely trigger for the mitochondrial release of AIF after cerebral ischemia.

Another important issue concerning the therapeutic potential of AIF inhibition is whether inhibition of AIF-mediated neuronal cell death would push cells toward caspase-3-mediated cell death. The current data clearly show that this is not the case for ischemic neuronal cell death because, in areas of the brain equally affected by ischemic damage, inhibition of PARP1 reduces AIF translocation significantly but leaves caspase-3 activation unaffected (Fig. 7B). The conclusion that PARP1/AIF-mediated neuronal cell death represents a pathway totally distinct from caspase-mediated cell death is also supported by the fact that PARP1-mediated cell death and AIF translocation cannot be affected by caspase inhibitors (Yu et al., 2002).

Based on the current data, we propose that cerebral ischemia leads, among others, to DNA damage and subsequent PARP1

B Control
A
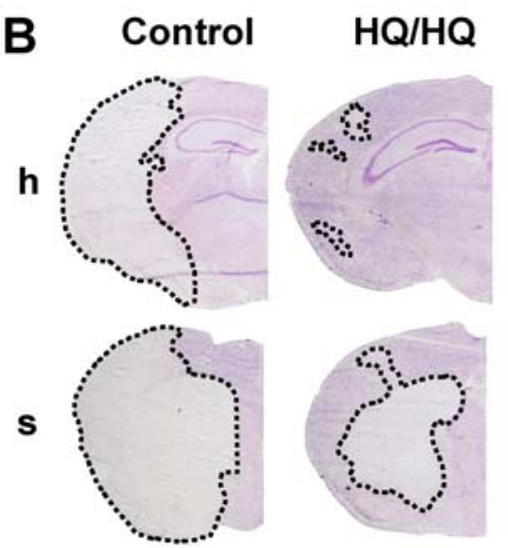

s

\section{C}

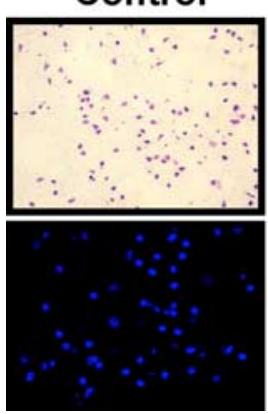

D
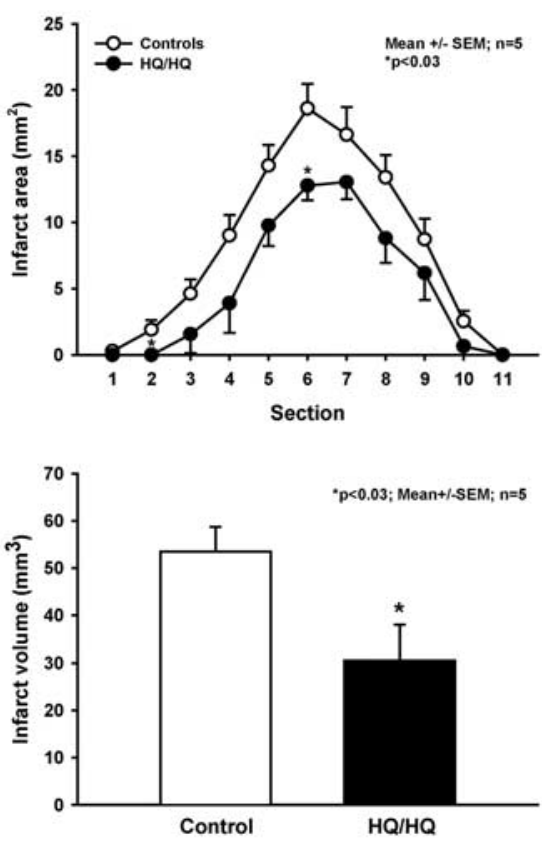

E

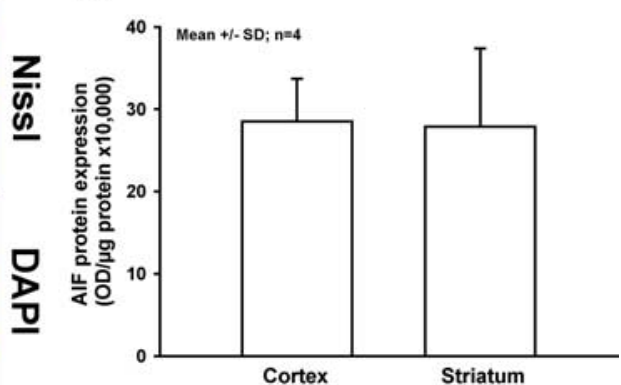

Figure 6. Significant reduction of ischemic brain damage in AIF low-expressing mice. $A$, Western blot analysis shows markedly reduced AIF protein levels in the brains of $\mathrm{HQ} / \mathrm{HQ}$ mice compared with homozygote wild-type $(+/+)$ and heterozygote $(+/ \mathrm{HQ})$ littermates. $\boldsymbol{B}$, Nissl-stained brain sections of hippocampal $(\mathrm{h})$ and striatal $(\mathrm{s})$ brain regions obtained $24 \mathrm{~h}$ after reperfusion demonstrate significant reduction of infarcted brain tissue in Harlequin mice compared with littermate controls. The squares indicate the areas shown at higher magnification in $\boldsymbol{C}$. $\boldsymbol{C}$, High-magnification photomicrographs of Nissl-stained sections from cortical areas indicated by squares in $\boldsymbol{B}$ show shrunken cells with pyknotic nuclei in the infarct area of wild-type littermates (Control), whereas the cells in the corresponding area in HQ mice show normal morphology (top row). Fluorescent photomicrographs of respective cortical areas in adjacent sections stained with DAPI show that all damaged neurons in the infarct area of wild-type animals have pyknotic nuclei, whereas almost all nuclei in the corresponding area in $\mathrm{HQ}$ mice appear normal (bottom row). $\boldsymbol{D}$, Infarct areas were evaluated histomorphometrically on 11 consecutive Nissl-stained brain sections (500 $\mu \mathrm{m}$ apart) throughout the infarct (top row). Note that, in each section, the mean infarct area was reduced in $\mathrm{HQ}$ mice compared with controls. The infarct volume was calculated on the basis of the histomorphometric data from the individual sections, showing a $43 \%$ reduction of the mean infarct volume in $\mathrm{HQ}$ mice compared with wild-type littermates (bottom row; ${ }^{*} p<0.03 ; n=5$ per group). $\boldsymbol{E}, \mathrm{HQ}$ mice displayed equal expression of AIF in cerebral cortex and striatum as shown by Western blot analysis $(n=4)$.

activation. PARP1 activation leads to a decrease of mitochondrial $\mathrm{NAD}^{+}$that induces Bcl-2-controlled and Bid-mediated translocation of AIF to the nucleus, in which it initiates nuclear condensation (Susin et al., 1999). In parallel, but independent of PARP1 activation and nuclear AIF translocation, caspases may contribute to additional ischemic brain damage (Namura et al., 1998; Le et al., 2002).

In addition to its proapoptotic function, it becomes more and more evident that AIF may also have apoptosis-independent bi- 
A
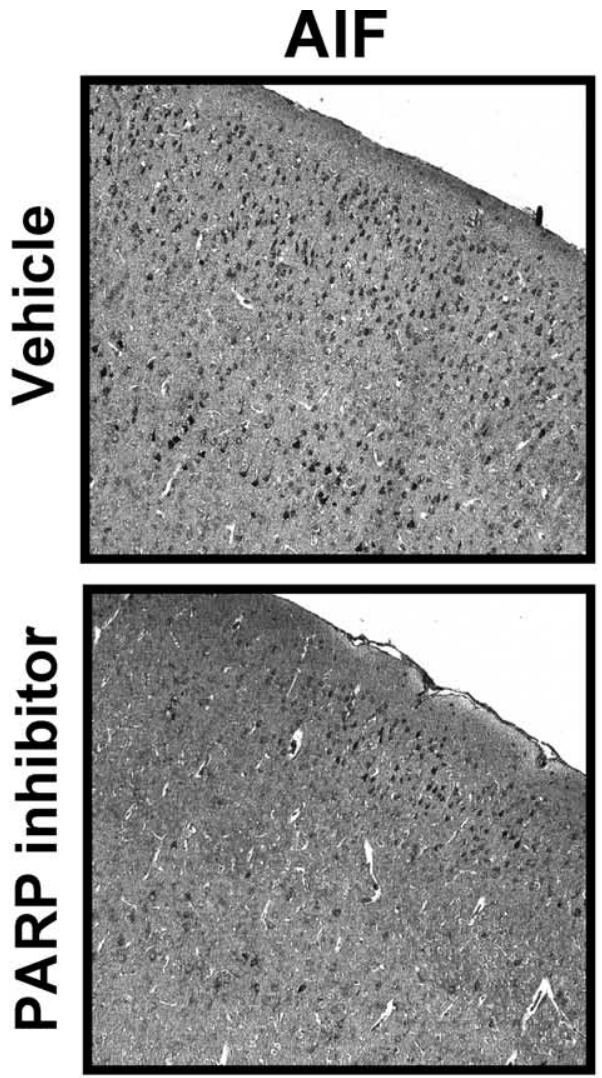

B

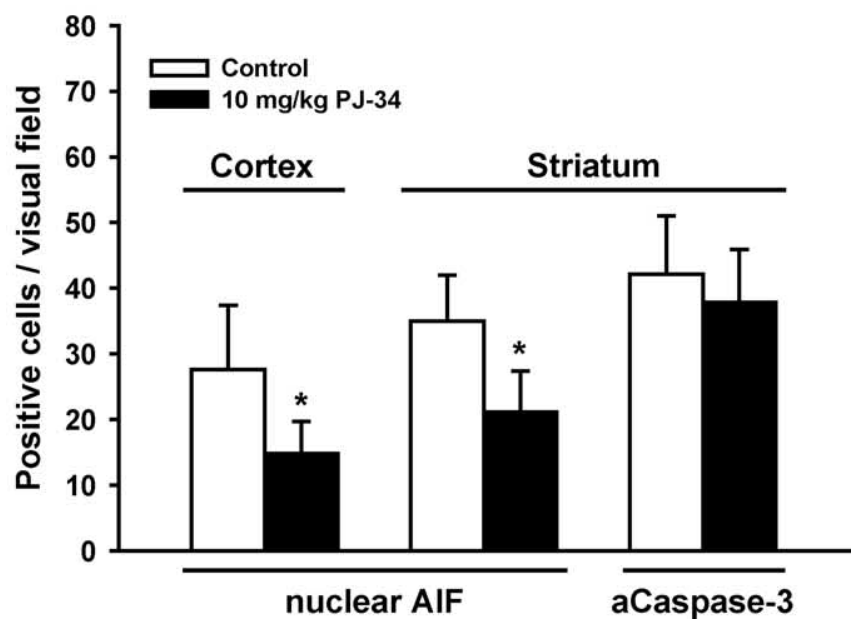

Figure 7. PARP1 inhibition reduces AIF translocation after cerebral ischemia. A, Immunohistochemical staining of AIF (black) in the cerebral cortex of control animals and of mice receiving $10 \mathrm{mg} / \mathrm{kg}$ of the selective PARP inhibitor PJ-34 intraperitoneally $15 \mathrm{~min}$ before MCA0. PARP inhibition reduces the number of neurons displaying nuclear AlF translocation. $\boldsymbol{B}$, Number of neurons in cerebral cortex and striatum displaying nuclear AIF or active caspase-3 staining (striatum only) in control animals (white bars) and in animals receiving a PARP inhibitor (black bars; see above). PARP inhibition reduced the number of neurons showing nuclear AlF by $40-$ $45 \%(n=5 ; p<0.01)$ but did not effect caspase- 3 activation.

ological roles, e.g., cells and mice with reduced AIF expression exhibit high lactate production attributable to reduced oxidative phosphorylation (Vahsen et al., 2004), as also supported by our data showing a tendency toward lower arterial $\mathrm{pH}$ in Harlequin mutant mice (Table 1). Interestingly, the reduced capability of
Harlequin mouse to use glucose by oxidative phosphorylation does not seem to play a detrimental role after cerebral ischemia and reperfusion, as shown by the profound neuroprotection observed in these animals. Hence, under pathophysiological conditions, the antiapoptotic effect of AIF depletion seems to overbalance the reduced capability of oxidative glucose utilization.

In conclusion, our findings demonstrate a key role for AIF in delayed neurodegeneration after experimental stroke, thereby providing the first evidence that AIF is a mediator of ischemichypoxic cell death in vitro and in vivo. These findings suggest that AIF is a novel target for drug development aimed at mitigating delayed cell death after stroke and other neurological and nonneurological diseases in which ischemic cell death is prominent.

\section{References}

Abdelkarim GE, Gertz K, Harms C, Katchanov J, Dirnagl U, Szabo C, Endres M (2001) Protective effects of PJ34, a novel, potent inhibitor of poly(ADP-ribose) polymerase (PARP) in in vitro and in vivo models of stroke. Int J Mol Med 7:255-260.

Arnoult D, Parone P, Martinou JC, Antonsson B, Estaquier J, Ameisen JC (2002) Mitochondrial release of apoptosis-inducing factor occurs downstream of cytochrome c release in response to several proapoptotic stimuli. J Cell Biol 159:923-929.

Becattini B, Sareth S, Zhai D, Crowell KJ, Leone M, Reed JC, Pellecchia M (2004) Targeting apoptosis via chemical design: inhibition of bidinduced cell death by small organic molecules. Chem Biol 11:1107-1117.

Cande C, Vahsen N, Garrido C, Kroemer G (2004) Apoptosis-inducing factor (AIF): caspase-independent after all. Cell Death Differ 11:591-595.

Cao G, Clark RS, Pei W, Yin W, Zhang F, Sun FY, Graham SH, Chen J (2003) Translocation of apoptosis-inducing factor in vulnerable neurons after transient cerebral ischemia and in neuronal cultures after oxygen-glucose deprivation. J Cereb Blood Flow Metab 23:1137-1150.

Charriaut-Marlangue C, Margaill I, Represa A, Popovici T, Plotkine M, Ben Ari Y (1996) Apoptosis and necrosis after reversible focal ischemia: an in situ DNA fragmentation analysis. J Cereb Blood Flow Metab 16:186-194.

Cheung EC, Melanson-Drapeau L, Cregan SP, Vanderluit JL, Ferguson KL, McIntosh WC, Park DS, Bennett SA, Slack RS (2005) Apoptosisinducing factor is a key factor in neuronal cell death propagated by BAXdependent and BAX-independent mechanisms. J Neurosci 25:1324-1334.

Chiarugi A (2005) Poly(ADP-ribosyl)ation and stroke. Pharmacol Res $52: 15-24$.

Cregan SP, Fortin A, MacLaurin JG, Callaghan SM, Cecconi F, Yu SW, Dawson TM, Dawson VL, Park DS, Kroemer G, Slack RS (2002) Apoptosisinducing factor is involved in the regulation of caspase-independent neuronal cell death. J Cell Biol 158:507-517.

Culmsee C, Gerling N, Lehmann M, Nikolova-Karakashian M, Prehn JH, Mattson MP, Krieglstein J (2002) Nerve growth factor survival signaling in cultured hippocampal neurons is mediated through TrkA and requires the common neurotrophin receptor P75. Neuroscience 115:1089-1108.

Daugas E, Susin SA, Zamzami N, Ferri KF, Irinopoulou T, Larochette N, Prevost MC, Leber B, Andrews D, Penninger J, Kroemer G (2000) Mitochondrio-nuclear translocation of AIF in apoptosis and necrosis. FASEB J 14:729-739.

Didenko VV, Tunstead JR, Hornsby PJ (1998) Biotin-labeled hairpin oligonucleotides: probes to detect double-strand breaks in DNA in apoptotic cells. Am J Pathol 152:897-902.

Didenko VV, Ngo H, Minchew CL, Boudreaux DJ, Widmayer MA, Baskin DS (2002) Caspase-3-dependent and -independent apoptosis in focal brain ischemia. Mol Med 8:347-352.

Endres M, Wang ZQ, Namura S, Waeber C, Moskowitz MA (1997) Ischemic brain injury is mediated by the activation of poly(ADPribose)polymerase. J Cereb Blood Flow Metab 17:1143-1151.

Fonfria E, Dare E, Benelli M, Sunol C, Ceccatelli S (2002) Translocation of apoptosis-inducing factor in cerebellar granule cells exposed to neurotoxic agents inducing oxidative stress. Eur J Neurosci 16:2013-2016.

Fujimura M, Morita-Fujimura Y, Noshita N, Sugawara T, Kawase M, Chan PH (2000) The cytosolic antioxidant copper/zinc-superoxide dismutase prevents the early release of mitochondrial cytochrome $\mathrm{c}$ in ischemic brain after transient focal cerebral ischemia in mice. J Neurosci 20:2817-2824. 
Graham SH, Chen J (2001) Programmed cell death in cerebral ischemia. J Cereb Blood Flow Metab 21:99-109.

Harrison DC, Roberts J, Campbell CA, Crook B, Davis R, Deen K, Meakin J, Michalovich D, Price J, Stammers M, Maycox PR (2000) TR3 death receptor expression in the normal and ischaemic brain. Neuroscience 96:147-160

Joza N, Susin SA, Daugas E, Stanford WL, Cho SK, Li CY, Sasaki T, Elia AJ, Cheng HY, Ravagnan L, Ferri KF, Zamzami N, Wakeham A, Hakem R, Yoshida H, Kong YY, Mak TW, Zuniga-Pflucker JC, Kroemer G, Penninger JM (2001) Essential role of the mitochondrial apoptosisinducing factor in programmed cell death. Nature 410:549-554.

Klein JA, Longo-Guess CM, Rossmann MP, Seburn KL, Hurd RE, Frankel WN, Bronson RT, Ackerman SL (2002) The harlequin mouse mutation downregulates apoptosis-inducing factor. Nature 419:367-374.

Komjati K, Mabley JG, Virag L, Southan GJ, Salzman AL, Szabo C (2004) Poly(ADP-ribose) polymerase inhibition protect neurons and the white matter and regulates the translocation of apoptosis-inducing factor in stroke. Int J Mol Med 13:373-382.

Krajewski S, Krajewska M, Ellerby LM, Welsh K, Xie Z, Deveraux QL, Salvesen GS, Bredesen DE, Rosenthal RE, Fiskum G, Reed JC (1999) Release of caspase-9 from mitochondria during neuronal apoptosis and cerebral ischemia. Proc Natl Acad Sci USA 96:5752-5757.

Le DA, Wu Y, Huang Z, Matsushita K, Plesnila N, Augustinack JC, Hyman BT, Yuan J, Kuida K, Flavell RA, Moskowitz MA (2002) Caspase activation and neuroprotection in caspase-3-deficient mice after in vivo cerebral ischemia and in vitro oxygen glucose deprivation. Proc Natl Acad Sci USA 99:15188-15193.

Liu Y, Peterson DA, Kimura H, Schubert D (1997) Mechanism of cellular 3-(4,5-dimethylthiazol-2-yl)-2,5-diphenyltetrazolium bromide (MTT) reduction. J Neurochem 69:581-593.

Lo EH, Dalkara T, Moskowitz MA (2003) Mechanisms, challenges and opportunities in stroke. Nat Rev Neurosci 4:399-415.

Martin-Villalba A, Herr I, Jeremias I, Hahne M, Brandt R, Vogel J, Schenkel J, Herdegen T, Debatin KM (1999) CD95 ligand (Fas-L/APO-1L) and tumor necrosis factor-related apoptosis-inducing ligand mediate ischemiainduced apoptosis in neurons. J Neurosci 19:3809-3817.

Mattson MP, Culmsee C, Yu ZF (2000) Apoptotic and antiapoptotic mechanisms in stroke. Cell Tissue Res 301:173-187.

Murakami K, Kondo T, Kawase M, Chan PH (1998) The development of a new mouse model of global ischemia: focus on the relationships between ischemia duration, anesthesia, cerebral vasculature, and neuronal injury following global ischemia in mice. Brain Res 780:304-310.

Namura S, Zhu J, Fink K, Endres M, Srinivasan A, Tomaselli KJ, Yuan J, Moskowitz MA (1998) Activation and cleavage of caspase-3 in apoptosis induced by experimental cerebral ischemia. J Neurosci 18:3659-3668.

Penninger JM, Kroemer G (2003) Mitochondria, AIF and caspases-rivaling for cell death execution. Nat Cell Biol 5:97-99.

Plesnila N, Zinkel S, Le DA, Amin-Hanjani S, Wu Y, Qiu J, Chiarugi A, Thomas SS, Kohane DS, Korsmeyer SJ, Moskowitz MA (2001) BID mediates neuronal cell death after oxygen/glucose deprivation and focal cerebral ischemia. Proc Natl Acad Sci USA 98:15318-15323.

Plesnila N, Zhu C, Culmsee C, Groger M, Moskowitz MA, Blomgren K (2004) Nuclear translocation of apoptosis-inducing factor after focal cerebral ischemia. J Cereb Blood Flow Metab 24:458-466.

Rossler OG, Giehl KM, Thiel G (2004) Neuroprotection of immortalized hippocampal neurones by brain-derived neurotrophic factor and Raf-1 protein kinase: role of extracellular signal-regulated protein kinase and phosphatidylinositol 3-kinase. J Neurochem 88:1240-1252.

Schubert D, Piasecki D (2001) Oxidative glutamate toxicity can be a component of the excitotoxicity cascade. J Neurosci 21:7455-7462.

Susin SA, Lorenzo HK, Zamzami N, Marzo I, Snow BE, Brothers GM, Man- gion J, Jacotot E, Costantini P, Loeffler M, Larochette N, Goodlett DR, Aebersold R, Siderovski DP, Penninger JM, Kroemer G (1999) Molecular characterization of mitochondrial apoptosis-inducing factor. Nature 397:441-446.

Susin SA, Daugas E, Ravagnan L, Samejima K, Zamzami N, Loeffler M, Costantini P, Ferri KF, Irinopoulou T, Prevost MC, Brothers G, Mak TW, Penninger J, Earnshaw WC, Kroemer G (2000) Two distinct pathways leading to nuclear apoptosis. J Exp Med 192:571-580.

Trapp T, Korhonen L, Besselmann M, Martinez R, Mercer E, Lindholm D (2003) Transgenic mice overexpressing XIAP in neurons show better outcome after transient cerebral ischemia. Mol Cell Neurosci 23:302-313.

Vahsen N, Cande C, Briere JJ, Benit P, Joza N, Larochette N, Mastroberardino PG, Pequignot MO, Casares N, Lazar V, Feraud O, Debili N, Wissing S, Engelhardt S, Madeo F, Piacentini M, Penninger JM, Schagger H, Rustin P, Kroemer G (2004) AIF deficiency compromises oxidative phosphorylation. EMBO J 23:4679-4689.

Velier JJ, Ellison JA, Kikly KK, Spera PA, Barone FC, Feuerstein GZ (1999) Caspase- 8 and caspase- 3 are expressed by different populations of cortical neurons undergoing delayed cell death after focal stroke in the rat. J Neurosci 19:5932-5941.

Wang H, Shimoji M, Yu SW, Dawson TM, Dawson VL (2003) Apoptosis inducing factor and PARP-mediated injury in the MPTP mouse model of Parkinson's disease. Ann NY Acad Sci 991:132-139.

Wang H, Yu SW, Koh DW, Lew J, Coombs C, Bowers W, Federoff HJ, Poirier GG, Dawson TM, Dawson VL (2004) Apoptosis-inducing factor substitutes for caspase executioners in NMDA-triggered excitotoxic neuronal death. J Neurosci 24:10963-10973.

Yin X, Luo Y, Cao G, Bai L, Pei W, Kuharsky D, Chen J (2002) Bid-mediated mitochondrial pathway is critical to ischemic neuronal apoptosis and focal cerebral ischemia. J Biol Chem 277:42074-42081.

Yu SW, Wang H, Poitras MF, Coombs C, Bowers WJ, Federoff HJ, Poirier GG, Dawson TM, Dawson VL (2002) Mediation of poly(ADP-ribose) polymerase-1-dependent cell death by apoptosis-inducing factor. Science 297:259-263.

Yuan CQ, Li YN, Zhang XF (2004) Down-regulation of apoptosis-inducing factor protein by RNA interference inhibits UVA-induced cell death. Biochem Biophys Res Commun 317:1108-1113.

Zhang X, Chen J, Graham SH, Du L, Kochanek PM, Draviam R, Guo F, Nathaniel PD, Szabo C, Watkins SC, Clark RS (2002) Intranuclear localization of apoptosis-inducing factor (AIF) and large scale DNA fragmentation after traumatic brain injury in rats and in neuronal cultures exposed to peroxynitrite. J Neurochem 82:181-191.

Zhao H, Yenari MA, Cheng D, Barreto-Chang OL, Sapolsky RM, Steinberg GK (2004) Bcl-2 transfection via herpes simplex virus blocks apoptosisinducing factor translocation after focal ischemia in the rat. J Cereb Blood Flow Metab 24:681-692.

Zhu C, Wang X, Hagberg H, Blomgren K (2000) Correlation between caspase- 3 activation and three different markers of DNA damage in neonatal cerebral hypoxia-ischemia. J Neurochem 75:819-829.

Zhu C, Qiu L, Wang X, Hallin U, Cande C, Kroemer G, Hagberg H, Blomgren K (2003) Involvement of apoptosis-inducing factor in neuronal death after hypoxia-ischemia in the neonatal rat brain. J Neurochem 86:306-317.

Zhu C, Wang X, Qiu L, Peeters-Scholte C, Hagberg H, Blomgren K (2004) Nitrosylation precedes caspase-3 activation and translocation of apoptosis-inducing factor in neonatal rat cerebral hypoxia-ischaemia. J Neurochem 90:462-471.

Zhu C, Wang X, Xu F, Bahr BA, Shibata M, Uchiyama Y, Hagberg H, Blomgren K (2005) The influence of age on apoptotic and other mechanisms of cell death after cerebral hypoxia-ischemia. Cell Death Differ 12:162-176. 